\title{
Monitoring Academic Studies of Turkish Lexicography: A Bibliometric Study of 84 Years*
}

\author{
Ferdi Bozkurt, Turkish Language and Literature Department, Open \\ Education Faculty, Anadolu University, Eskişehir, Turkey \\ (ferdib@anadolu.edu.tr)
}

\begin{abstract}
The aim of this article is to report the main trends of the research texts written in Turkish in the field of Turkish lexicography. This report will also provide an opportunity to discuss the main trends in Turkish lexicography and the areas that need to be developed. The study is a descriptive research and literature review that is limited to the texts written in the Turkish language on Turkish linguistics during the years 19321-2016. The Turkish Academic Network and Information Center (ULAKBIM), Google Scholar, the Turkey Council of Higher Education Thesis Center, the Turkey National Collective Catalog, National Library of Turkey, EBSCOhost, ProQuest Dissertations \& Theses Global databases and 68 academic journals published on Turkish linguistics were searched for the study. The database contains 1001 texts. Findings related to these texts show that studies on lexicography have increased in recent years. Moreover, the findings show that there is a lack of some text types.
\end{abstract}

Keywords: TURKISH LEXICOGRAPHY, LEXICOGRAPHIC TEXTS, BOOKS, MASTER'S THESES, DOCTORAL DISSERTATIONS, REVIEWS, NEWS, RESEARCH TRENDS, BIBLIOMETRICS, CITATIONS, SCIENTIFIC IMPACT

Opsomming: Monitering van akademiese studies oor die Turkse leksikografie: ' $n$ Bibliometriese studie van $\mathbf{8 4}$ jaar. Die doel van hierdie artikel is om verslag te doen oor die hooftendense in die navorsingstekste geskryf in Turks op die gebied van die Turkse leksikografie. Hierdie verslag sal ook die geleentheid bied om die hooftendense in die Turkse leksikografie en die areas wat ontwikkeling benodig, te bespreek. Dié navorsing is 'n beskrywende navorsings- en literatuurverslag wat beperk is tot die tekste wat in Turks oor die Turkse linguistiek gedurende die jare 1932-2016 verskyn het. Die Turkse Akademiese Netwerk- en Inligtingsentrum (ULAKBIM), Google Scholar, die Turkse Raad van Hoër Onderwys se Tesissentrum, die Turkse Nasionale Gesamentlike Katalogus, die Nasionale Biblioteek van Turkye, EBSCOhost, ProQuest Dissertations \& Theses Global se databasisse en 68 akademiese joernale wat in die Turkse linguistiek gepubliseer word, is vir hierdie studie deursoek. Die databasis bevat 1001 tekste. Bevindings

* An earlier version of this article was presented at the 12th International Conference of the Asian Association for Lexicography (ASIALEX 2018), which was hosted by the King Mongkut's Institute of Technology Ladkrabang in Krabi, Thailand, 8-10 June 2018.

Lexikos 29 (AFRILEX-reeks/series 29: 2019): 288-315 
rakende hierdie tekste dui daarop dat studies in die leksikografie in die afgelope jare toegeneem het. Bowenal toon die bevindings dat daar 'n gebrek aan sommige tekssoorte is.

Sleutelwoorde: TURKSE LEKSIKOGRAFIE, LEKSIKOGRAFIESE TEKSTE, BOEKE, MEESTERSPROEFSKRIFTE, DOKTORALE VERHANDELINGS, RESENSIES, NUUS, NAVORSINGSTENDENSE, BIBLIOMETRIE, SITATE, WETENSKAPLIKE IMPAK

\section{Introduction}

In the digital age we are in, more and more information is being produced every day. Information is expanding in a variety of fields, such as education, culture, art, technology and science, and is spreading faster than ever before this century. The case is also inevitably the same in linguistics. More information is produced in the field of lexicography, where some researchers are still debating whether it is a branch of science itself or a sub-branch of linguistics (Atkins and Rundell 2008; Bergenholtz and Gouws 2012; Landau 1984; Tarp 2012; Zgusta 1971). As a result of academic studies in lexicography, texts like books, articles, presentations, reviews, etc. have emerged.

\subsection{Lexicographic tradition of the Turkish language}

The first known dictionary study for the Turkish language began with Mahmut Kashgar. He completed Divânu Lügati't-Türk (Dictionary of Turkish Languages) in February 1074 (Ercilasun and Akkoyunlu 2014). Divânu Lügati't-Türk accepted that the basis of Turkish lexicography accords well with the principles of Arabic lexicography.

All dictionaries prepared in the Ottoman period from 1074 to 1901 were translated from Arabic and Persian. And in these dictionaries, headwords were of Arabic and Persian origin. These dictionaries were prepared according to the principles of the Arabic lexicographic tradition (Yavuzarslan 2017). One of the main reasons for this situation was the need for language learning among different nations as a result of the increase in commercial, scientific and religious interaction of Muslim Turks with Arabs and Persians.

In the Turkish lexicographic tradition, the most typical example of the transition from Arabic lexicography to Western lexicography is the Kamus- $\imath$ Türkî published in 1901. The lexicographic concept in Kâmûs-ı Türkî is based especially on the works of the late 1800s, the last period of the Ottoman Empire. Some researchers (Dilaçar 1953; Gökçe 1998; Parlatır 1995) studied bilingual or annotated dictionaries of this period. While the dictionaries before Kâmûs-ı Türkî contained only Arabic or Persian headwords, Turkish headwords were used for the first time in Kâmûs-ı Türkî. 
The dictionaries compiled before the Republic of Turkey emerged as the result of individual efforts. Normally, dictionaries compiled by means of group work are regarded as more scientific. However dictionaries such as Lehçetü'llügat (1796) compiled by Şeyhülislam Esad Efendi and Kâmûs-ı Türk̂̂ (1901) compiled by Şemseddin Sami are accepted masterpieces of Turkish lexicography.

Mustafa Kemal Atatürk made great strides in language studies as in many other fields of science after he had founded the Republic of Turkey on October 29, 1923. Atatürk, by both creating official institutions and participating personally in Turkish linguistic studies, coined new Turkish geometry terms to replace the geometry terms of Arabic-Persian origin from the Ottoman tradition. He also wrote a geometry book using the new terminology. Moreover, he provided government support for Turkish linguistic studies. The Turkish Language Association, which was established on July 12, 1932, triggered linguistic studies such as morphology, syntax, lexicology, phonetics, semantics, and etymology. Since linguistic studies were largely supported financially by the Republic of Turkey, there was a significant increase in scientific studies. As a result of these studies, books, doctoral dissertations, articles, presentations, bulletins, and scientific research projects were produced.

\subsection{Bibliometrics}

According to Day and Gastel (1995: ix) "the goal of scientific research is publication". Publications as a result of scientific research are therefore absolutely important. The mathematical and statistical review of the publications by means of scientific methodology, in other words, by determining their quantitative distribution by using statistical analysis, will contribute to determine the direction of development in lexicographic studies.

It is important to illustrate the impact of scientific studies such as articles, master's theses, doctoral dissertations and presentations written in the field of science.

The most important contributions of illustrating this scientific trend is to:

- indicate the distribution of these texts according to their types and citations,

- show the effects of the institutions contributing to the creation of the texts and the characteristics of the journals that provide the texts to the researchers, and

- identify the researchers producing the texts and the types of their scientific texts that contribute to the field.

It was Alan Pritchard who first introduced the term bibliometrics into the scientific literature in 1969. Pritchard (1969: 348) described bibliometrics as the "application of mathematics and statistical methods to books and other media of com- 
munication". This explanation was extended by Potter (1981: 5) who redefined it as: "Bibliometrics is, simply put, the study and measurement of the publication patterns of all forms of written communication and their authors." Therefore, the relationships between the authors and the texts are also included in the concept. With the help of bibliometrics, it is possible to quantify the number and distribution of contributions in the literature. This approach is very useful to determine the development of knowledge in the literature.

Hulme (1923) believed that "statistical treatment must show the existence of phases of activity and retardation in each science and might even indicate approximately the period when its ultimate boundaries would be reached". This issue is very important for academic professionals in terms of the formation of the literature in their field of study because it is necessary to examine previous studies and conduct field research for today's scientific approaches. In order to see the scientific impact of the studies conducted in different fields, very important measurement platforms such as the Science Citation Index (SCI), established in 1955 by Eugene Garfield (1955), were created. These indexes facilitate the acquisition of information on the effectiveness of scientific publications and have become systematic over time.

Nowadays, bibliometric studies are carried out on a wide range of disciplines and it is possible to encounter bibliometric studies on linguistics. For instance, Lei and Liu (2018) conducted a study which covers 42 journals of applied linguistics mentioned in the Social Science Citation Index (SSCI). Mohsen et al. (2017) conducted a study on linguistic publications which appeared during the years 2005-2014 and which were included in the Thomson Reuters' Social Science Citation Index (SSCI). Arik (2015) reviewed the articles published during 1900-2013 and mentioned in the Social Science Citation Index (SSCI), and discussed the characteristics of the linguistic articles included in the Arts and Humanities Citation Index (A and HCI) between 1975 and 2013. Lei and Liao (2017) examined the linguistic publications by researchers from China, Hong Kong, Taiwan, and Macau between 2003 and 2012, and they identified high-impact and popular journals by applying the bibliometrics method regionally.

\subsection{Bibliometrics in lexicography}

In the field of lexicography, De Schryver (2009a; 2009b) conducted analysis studies on internationally important journals such as the International Journal of Lexicography and Lexikos. In the first of his articles, De Schryver (2009a) built a corpus from the studies published in the International Journal of Lexicography (IJL), which is one of the most important journals in the field of lexicography, and conducted a detailed content analysis as well as a citation analysis accordingly. He made comparisons between the important journals of linguistics (Linguistics and Applied Linguistics) and lexicography (Lexikos and Dictionary). In his second article, De Schryver (2009b) conducted research on Lexikos, making a 
statistical analysis of this journal covering 18 years. Both of these studies are very important in terms of presenting contributions to the field of lexicography.

The number of bibliographic studies in the field of Turkish lexicography are rather limited. In this field, generally, bibliographic studies about the prepared dictionaries and the reviews of these dictionaries are made (Eminoğlu 2010; Kotan 2017). The study of Y1kmış and Sazak (2017) identified 31 book chapters, 106 theses, 188 presentations, 23 reviews and 219 articles related to lexicography. The study of Y1kmış and Sazak (2017) is limited to the years 2000 and 2016. These two researchers divided the texts into text types such as books, book chapters, doctoral dissertations, master's theses, presentations, reviews and articles.

In the mentioned studies, it is not possible to find a large literature on Turkish lexicography. In addition, the impact and type of the publications, and cooperative ways among the authors were not discussed statistically. The original aspect of this study lies in the fact that it is the first bibliometric study on Turkish lexicography. One of the strengths of the study is the bibliometric analysis of lexicography at the level of a particular country through all available scientific texts produced in the field of Turkish lexicography.

The main objectives of the current study are to:

- find out the authorship pattern,

- calculate the degree of collaboration,

- determine distributions of the institutional contributions to the texts,

- find out the self citation ratio of an author,

- determine the most cited texts, and

- determine the most productive authors.

\section{Data and methodology}

This study involves texts produced between the years 1932 and 2016. The reason for adopting 1932 as the starting year is that the Turkish Language Institution was established in that year.

It was necessary to create a list of keywords and a set of criteria for the data set used in the study because there are thousands of Turkish articles, presentations and theses produced in the field of morphology, syntax, phonetics, phonology, psycholinguistics, sociolinguistics, computational linguistics, historical linguistics, applied linguistics, etc. 


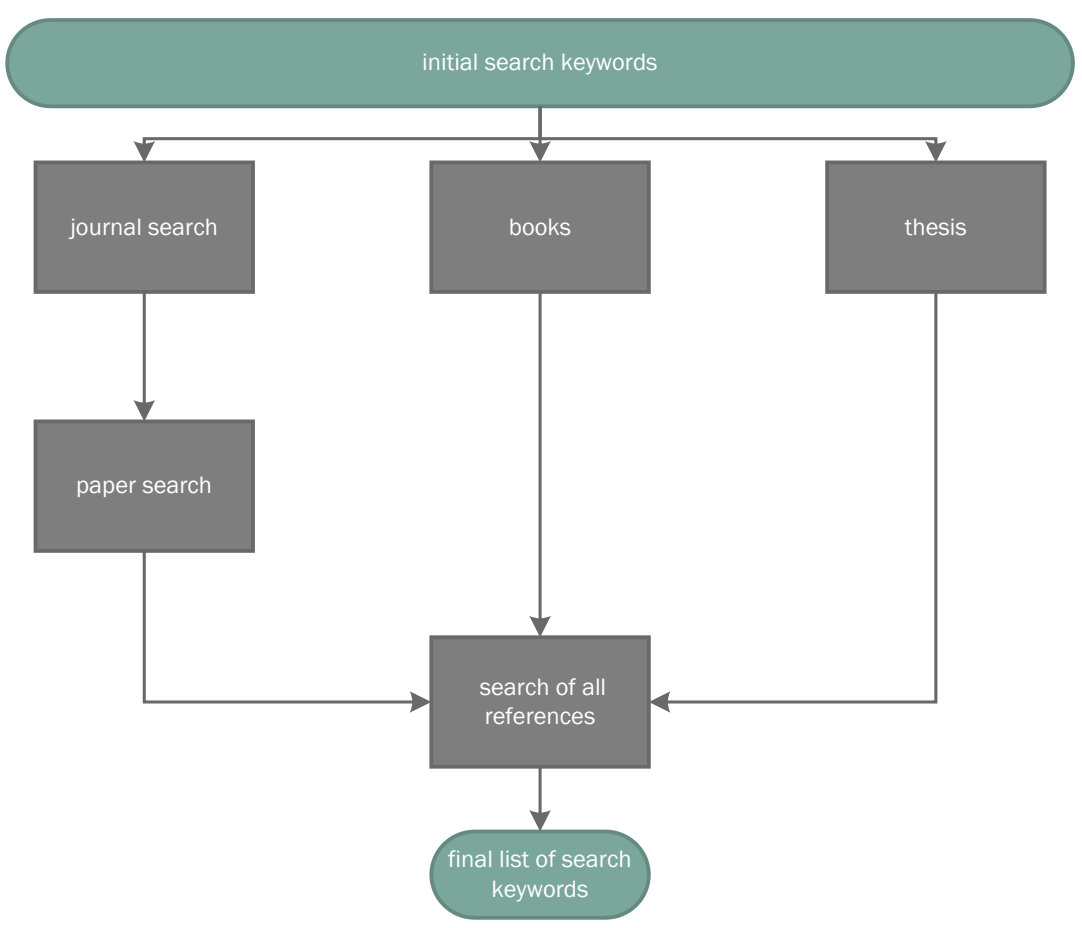

Figure 1: Determining the final search keyword list

In order to differentiate the texts related to lexicography, firstly, sözlïk (lexicon) and sözlük bilim (lexicology) were determined as initial search keywords. These initial search keywords were queried in 68 journals, written in Turkish and published in the field of linguistics and grammar. Afterwards, queries were made in Google Scholar with these initial keywords. In the obtained texts, it was found that the Turkish word sözlük (dictionary) and the Arabic word lügat (dictionary), and sözlükbilim and leksikografi were used synonymously. The word sözlük bilim (lexicography) was used with different spelling variants such as sözlükbilim, sözlükbilimi and sözlük bilimi. In addition, the texts in the reference list sections of the articles encountered during the queries made with initial keywords were also examined. Thus the following were accepted as final search keywords: sözlük (dictionary), lügat (dictionary, an old usage), sözlükbilim (lexicography), sözlük bilim (lexicography), sözlükbilimi (lexicography), sözlük bilimi (lexicography), sözlükçülük (synonymous with lexicography), leksikografi (lexicography).

As a result of these inquiries, a process sequence was followed to create the final keyword list. 


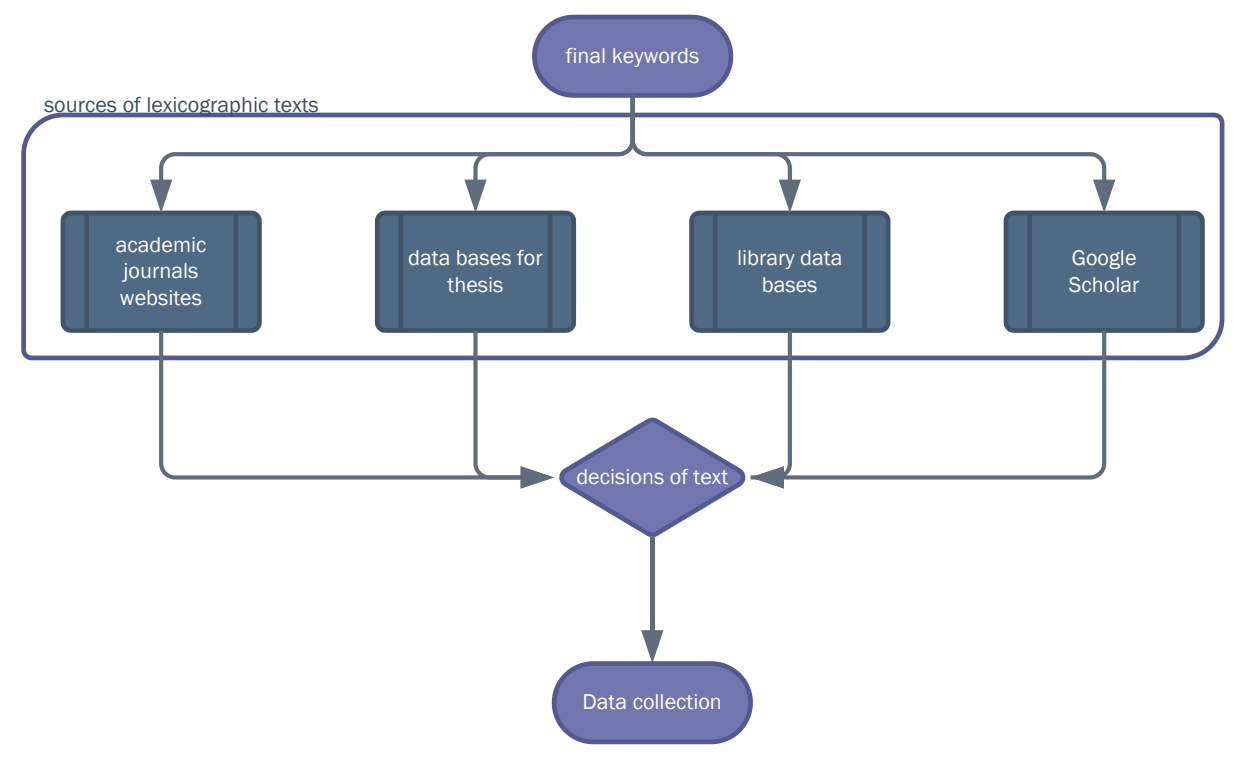

Figure 2: Selecting the target texts

In order to investigate the articles, the Turkish Academic Network and Information Center (ULAKBIM) ${ }^{2}$, Google Scholar ${ }^{3}$, EBSCOhost ${ }^{4}$, the Turkey National Collective Catalog 5 , the National Library of Turkey ${ }^{6}$, websites of 76 journals publishing articles on linguistics and Turcology, and the reference list of determined articles were searched.

The Turkey Council of Higher Education Thesis Center ${ }^{7}$ and the ProQuest Dissertations \& Theses Global ${ }^{8}$ were scanned for master's theses and doctoral dissertations.

The books were determined after analyzing the reference lists of the articles found in Google Scholar and in the libraries of Anadolu University and Eskişehir Osmangazi University.

Approximately 2,873 scientific texts were obtained following the searches. However, in most of the texts, although one of the final keywords was sözlük (dictionary), it was found that the text was not related to lexicography when it was examined. Another case is that in the Turkish abstract and keywords list of 124 articles whose main texts were written in English, German and French, dictionary and lexicography words were found; however, these texts were removed from the database of this study since the database would be composed of articles written only in Turkish. Then, the lexicographic text decision stage shown in Figure 2 was in progress. The researcher decided whether the content of the texts was related to lexicography or not by examining the content of the texts one by one. 
Table 1: Text types determined for the current study

\begin{tabular}{lcc}
\hline Text Type & Number of Texts & $\%$ \\
\hline Doctoral dissertations & 12 & 1.20 \\
Master's theses & 39 & 3.90 \\
Published oral presentations & 301 & 30.07 \\
News & 21 & 2.10 \\
Books & 3 & 0.30 \\
Articles & 475 & 47.45 \\
Reviews & 150 & 14.99 \\
Total & 1001 & 100.00 \\
\hline
\end{tabular}

As a result of the last stage, the texts in Table 1 have formed the database of this research.

\section{Data analysis and interpretation}

Frequency and percentage values of publication years are shown in Table 2:

Table 2: Number of publications by year

\begin{tabular}{|c|c|c|c|c|c|c|c|c|}
\hline Year & Frequency & $\%$ & Year & Frequency & $\%$ & Year & Frequency & $\%$ \\
\hline 1934 & 1 & 0.10 & 1973 & 2 & 0.20 & 1996 & 9 & 0.90 \\
\hline 1935 & 2 & 0.20 & 1974 & 2 & 0.20 & 1997 & 5 & 0.50 \\
\hline 1936 & 3 & 0.30 & 1975 & 13 & 1.30 & 1998 & 15 & 1.50 \\
\hline 1939 & 2 & 0.20 & 1976 & 5 & 0.50 & 1999 & 31 & 3.10 \\
\hline 1942 & 1 & 0.10 & 1977 & 6 & 0.60 & 2000 & 16 & 1.60 \\
\hline 1952 & 2 & 0.20 & 1979 & 1 & 0.10 & 2001 & 5 & 0.50 \\
\hline 1953 & 3 & 0.30 & 1980 & 2 & 0.20 & 2002 & 18 & 1.80 \\
\hline 1954 & 6 & 0.60 & 1981 & 2 & 0.20 & 2003 & 8 & 0.80 \\
\hline 1956 & 2 & 0.20 & 1982 & 3 & 0.30 & 2004 & 22 & 2.20 \\
\hline 1957 & 1 & 0.10 & 1983 & 1 & 0.10 & 2005 & 12 & 1.20 \\
\hline 1959 & 3 & 0.30 & 1984 & 1 & 0.10 & 2006 & 21 & 2.10 \\
\hline 1960 & 3 & 0.30 & 1985 & 2 & 0.20 & 2007 & 63 & 6.29 \\
\hline 1961 & 1 & 0.10 & 1986 & 2 & 0.20 & 2008 & 84 & 8.39 \\
\hline 1962 & 2 & 0.20 & 1987 & 2 & 0.20 & 2009 & 111 & 11.09 \\
\hline 1963 & 1 & 0.10 & 1989 & 1 & 0.10 & 2010 & 59 & 5.89 \\
\hline 1965 & 2 & 0.20 & 1990 & 1 & 0.10 & 2011 & 68 & 6.79 \\
\hline 1967 & 2 & 0.20 & 1991 & 4 & 0.40 & 2012 & 46 & 4.60 \\
\hline 1968 & 1 & 0.10 & 1992 & 1 & 0.10 & 2013 & 70 & 6.99 \\
\hline 1969 & 2 & 0.20 & 1993 & 1 & 0.10 & 2014 & 52 & 5.19 \\
\hline 1970 & 1 & 0.10 & 1994 & 5 & 0.50 & 2015 & 61 & 6.09 \\
\hline 1971 & 4 & 0.40 & 1995 & 8 & 0.80 & 2016 & 98 & 9.79 \\
\hline 1972 & 17 & 1.70 & \multicolumn{4}{|c|}{ Total } & 1001 & 100.00 \\
\hline
\end{tabular}


Table 2 shows the distribution of texts in the field of Turkish lexicography by year. As can be seen in the table, the years when most texts about lexicography were produced in Turkey are the following: 2009 (111 texts), 2016 (98 texts), 2008 (84 texts), 2013 (70 texts), 2011 (68 texts). In some years (1937, 1938, 1940, 1941) no texts were produced. However, texts have been produced annually and uninterruptedly in the field of lexicography since 1967. This study covers the years between 1932 and 2016, the average number of texts being 11.9 during these years. As shown in Table 2, only one text was produced in some years $(1968,1983,1984$ etc.). In addition, as can be seen in the table, an increase has been observed in the number of texts related to lexicography over the last 20 years.

\subsection{Lexicographic research texts}

\subsubsection{Doctoral dissertations}

By limiting the years to 1932-2016 in the Turkey Council of Higher Education Thesis Center, 252 master's theses and 50 doctoral dissertations were found as a result of the searches in which lügat (dictionary) and sözlük (dictionary, an old usage) were the keywords. During the search, it was found that 25 doctoral dissertations were not accessible. Master's theses and doctoral dissertations prepared in the field of history, geography and Islamic sciences and not related to lexicography were emerging as a result of the search. The reason for this was the dictionary sections in the form of indexes added by the researcher to the last parts of the theses. In addition, especially in the theses prepared for the transfer of old texts written in Arabic letters to modern Turkish, researchers added dictionary sections to the last sections of the studies. This resulted in high numbers of search results. On the other hand, it was observed that terms such as sözlük (dictionary) and lügat (dictionary, an old usage) were used in grammar studies on texts. In the Turkish Council of Higher Education Thesis Center, because these terms were used in some studies written in English, German, French, Persian and Spanish and conducted in the field of Western and Eastern languages, the number of search results were extremely high. Since only theses written in Turkish are in the scope of the current study, theses other than Turkish were excluded. Moreover, in the Turkish Council of Higher Education Thesis Center, only the abstracts of the studies conducted in the previous years, such as 1956, 1962, 1985, could be seen and the full texts could not be accessed. While selecting the master's theses and doctoral dissertations in the field of lexicography, the keywords in the research scope were queried. Of 302 graduate studies, 230 provided with full-text access were read and examined by the researcher individually, and 51 master's theses and doctoral dissertations to be included in the research were determined. 
Table 3: Doctoral dissertations by year

\begin{tabular}{ccc}
\hline Year & Frequency & $\%$ \\
\hline 1993 & 1 & 8.33 \\
2000 & 1 & 8.33 \\
2007 & 1 & 8.33 \\
2009 & 2 & 16.67 \\
2010 & 3 & 25.00 \\
2011 & 2 & 16.67 \\
2013 & 1 & 8.33 \\
2016 & 1 & 8.33 \\
Total & $\mathbf{1 2}$ & $\mathbf{1 0 0 . 0 0}$ \\
\hline
\end{tabular}

As can be seen in Table 3, the first doctoral dissertation that met the criteria for the database of the current study was conducted in 1993. The highest number of doctoral dissertations produced were in the year 2010 (3 doctoral dissertations).

Table 4: Universities and institutes producing doctoral dissertations

\begin{tabular}{|c|c|c|c|c|}
\hline University & Institute & Department & Number & $\begin{array}{c}\text { Percentage } \\
\text { value of total } \\
\text { doctoral } \\
\text { dissertations }\end{array}$ \\
\hline \multirow[t]{2}{*}{ Ankara University } & $\begin{array}{l}\text { Institute of Social } \\
\text { Sciences }\end{array}$ & $\begin{array}{l}\text { Eastern Linguistics and Literature } \\
\text { (Arabic Language and Literature) }\end{array}$ & 1 & 8,33 \\
\hline & $\begin{array}{l}\text { Institute of Social } \\
\text { Sciences }\end{array}$ & $\begin{array}{l}\text { Department of Turkish Language and } \\
\text { Literature }\end{array}$ & 1 & 8,33 \\
\hline \multirow[t]{2}{*}{ Atatürk University } & $\begin{array}{l}\text { Institute of Social } \\
\text { Sciences }\end{array}$ & Department of Basic Islamic Studies & 1 & 8,33 \\
\hline & $\begin{array}{l}\text { Institute of Social } \\
\text { Sciences }\end{array}$ & $\begin{array}{l}\text { Department of Turkish Language and } \\
\text { Literature }\end{array}$ & 1 & 8,33 \\
\hline \multirow[t]{2}{*}{ Çukurova University } & $\begin{array}{l}\text { Institute of } \\
\text { Educational Sciences }\end{array}$ & $\begin{array}{l}\text { Department of German Language and } \\
\text { Literature }\end{array}$ & 1 & 8,33 \\
\hline & $\begin{array}{l}\text { Institute of Social } \\
\text { Sciences }\end{array}$ & $\begin{array}{l}\text { Department of Turkish Language and } \\
\text { Literature }\end{array}$ & 1 & 8,33 \\
\hline Dicle University & $\begin{array}{l}\text { Institute of } \\
\text { Educational Sciences }\end{array}$ & $\begin{array}{l}\text { Department of Social Fields } \\
\text { Education (Turkish Language } \\
\text { Education) }\end{array}$ & 1 & 8,33 \\
\hline Eskişehir Osmangazi University & $\begin{array}{l}\text { Institute of Social } \\
\text { Sciences }\end{array}$ & $\begin{array}{l}\text { Department of Turkish Language and } \\
\text { Literature }\end{array}$ & 1 & 8,33 \\
\hline Gazi University & $\begin{array}{l}\text { Institute of Social } \\
\text { Sciences }\end{array}$ & $\begin{array}{l}\text { Department of Turkish Language and } \\
\text { Literature }\end{array}$ & 1 & 8,33 \\
\hline İstanbul University & $\begin{array}{l}\text { Institute of Social } \\
\text { Sciences }\end{array}$ & $\begin{array}{l}\text { Department of Turkish Language and } \\
\text { Literature }\end{array}$ & 1 & 8,33 \\
\hline Marmara University & $\begin{array}{l}\text { Institute of Social } \\
\text { Sciences }\end{array}$ & $\begin{array}{l}\text { Department of Turkish Language and } \\
\text { Literature }\end{array}$ & 1 & 8,33 \\
\hline Yeditepe University & $\begin{array}{l}\text { Institute of Social } \\
\text { Sciences }\end{array}$ & Department of Anthropology & 1 & 8,33 \\
\hline
\end{tabular}

Table 4 shows the institutes and departments where doctoral dissertations were conducted. According to this, the maximum number of doctoral dissertations in the field of lexicography were written in Ankara University (2), Atatürk University (2) and Çukurova University (2). When the characteristics and types of the institutes are considered, 10 of the 12 doctoral theses conducted in the field of lexicography were written in the Institute of Social Sci- 
ences, and only two of them were written in the Institute of Educational Sciences. It was found that the maximum number of doctoral dissertations (total 7) were written in the Department of Turkish Language and Literature.

Table 5: Doctoral dissertation advisor

\begin{tabular}{lcc}
\hline Name of Dissertation Advisor & $\begin{array}{c}\text { Number of PhD Dissertations } \\
\text { Supervised }\end{array}$ & $\begin{array}{c}\text { Total Percentage Value of } \\
\text { Doctoral Dissertations }\end{array}$ \\
\hline İsmail Hakkı Aksoyak & 2 & 16.6 \\
Erdoğan Boz & 1 & 8,33 \\
Feza Tansuğ & 1 & 8,33 \\
Gülden Sağol Yüksekkaya & 1 & 8,33 \\
Leyla Uzun \& Rahmi Er & 1 & 8,33 \\
Mustafa Özkan & 1 & 8,33 \\
Sadettin Özçelik & 1 & 8,33 \\
Şükrü Haluk Akalın & 1 & 8,33 \\
Süleyman Tülücü & 1 & 8,33 \\
Tahir Balcı & 1 & 8,33 \\
Turgut Karabey & 1 & 8,33 \\
TOTAL & $\mathbf{1 2}$ & $\mathbf{1 0 0 . 0 0}$ \\
\hline
\end{tabular}

As can be seen in Table 5, 12 doctoral dissertations were written under the supervision of 11 different academics. İsmail Hakkı Aksoyak is the academic who supervised the most doctoral dissertations. When the number of supervisors of doctoral dissertations are considered, it can be seen that 11 doctoral dissertations were conducted with one supervisor and only one doctoral dissertation was conducted with two supervisors.

\subsubsection{Master's theses}

Table 6: Master's theses by year

\begin{tabular}{ccc}
\hline Year & Frequency & \% \\
\hline 1996 & 1 & 2.56 \\
1997 & 1 & 2.56 \\
2005 & 1 & 2.56 \\
2006 & 2 & 5.13 \\
2007 & 6 & 15.38 \\
2008 & 1 & 2.56 \\
2009 & 3 & 7.69 \\
2010 & 4 & 10.26 \\
2011 & 4 & 10.26 \\
2012 & 5 & 12.82 \\
2013 & 4 & 10.26 \\
2014 & 2 & 5.13 \\
2015 & 5 & 12.82 \\
Total & 39 & $\mathbf{1 0 0 . 0 0}$
\end{tabular}


Master's theses seem to have increased in recent years as shown in Table 6 . The year in which master's theses were the most frequently conducted is 2007. Especially since 2006, it is seen that master's theses have been conducted more than once. Since 2009, there has been a steady increase in the number of master's theses.

Table 7: Universities and institutes producing master's theses

\begin{tabular}{|c|c|c|c|c|}
\hline University & Institute & Department & $\begin{array}{l}\text { Number of } \\
\text { Master's Theses }\end{array}$ & $\begin{array}{c}\text { Total Percentage } \\
\text { Value of Master's } \\
\text { Theses }\end{array}$ \\
\hline \multirow[t]{3}{*}{ Ankara University } & Institute of Social Sciences & Department of Linguistics & 3 & 7,69 \\
\hline & & $\begin{array}{l}\text { Eastern Linguistics and Literature (Arabic Language } \\
\text { and Literature) }\end{array}$ & 1 & 2,56 \\
\hline & & Department of Turkish Language and Literature & 1 & 2,56 \\
\hline $\begin{array}{l}\text { Eskişehir Osmangazi } \\
\text { University }\end{array}$ & Institute of Social Sciences & Department of Turkish Language and Literature & 5 & 12,82 \\
\hline Marmara University & Institute of Educational Sciences & Department of Turkish Language Education & 4 & 10,25 \\
\hline \multirow[t]{2}{*}{ Sakarya University } & Institute of Educational Sciences & Department of Turkish Language Education & 2 & 5,12 \\
\hline & Institute of Social Sciences & Department of Turkish Language and Literature & 1 & 2,56 \\
\hline \multirow[t]{2}{*}{ Afyon Kocatepe University } & Institute of Educational Sciences & Department of Turkish Language Education & 1 & 2,56 \\
\hline & Institute of Social Sciences & Department of Turkish Language and Literature & 1 & 2,56 \\
\hline \multirow[t]{2}{*}{ Gazi University } & Institute of Social Sciences & Department of Turkish Language and Literature & 1 & 2,56 \\
\hline & $\begin{array}{l}\text { Institute of Science and } \\
\text { Technology }\end{array}$ & Department of Computer Engineering & 1 & 2,56 \\
\hline \multirow[t]{2}{*}{ Yıldız Technical University } & Institute of Social Sciences & Department of Turkish Language and Literature & 1 & 2,56 \\
\hline & Institute of Social Sciences & $\begin{array}{l}\text { Department of Translation and Interpretation } \\
\text { (Department of French Language) }\end{array}$ & 1 & 2,56 \\
\hline İstanbul University & Institute of Social Sciences & Department of Turkish Studies & 1 & 2,56 \\
\hline İstanbul Aydın University & Institute of Social Sciences & Department of Turkish Language and Literature & 1 & 2,56 \\
\hline Atatürk University & Institute of Social Sciences & Department of Turkish Language and Literature & 1 & 2,56 \\
\hline Dokuz Eylül University & Institute of Educational Sciences & $\begin{array}{l}\text { Department of Teaching Turkish as a Foreign } \\
\text { Language }\end{array}$ & 1 & 2,56 \\
\hline Ege University & Institute of Social Sciences & $\begin{array}{l}\text { Turkish World Studies (Turkish Languages and } \\
\text { Dialects) }\end{array}$ & 1 & 2,56 \\
\hline $\begin{array}{l}\text { Fatih Sultan Mehmet Vakıf } \\
\text { University }\end{array}$ & Institute of Social Sciences & Department of Turkish Language and Literature & 1 & 2,56 \\
\hline Frrat University & Institute of Educational Sciences & Department of Turkish Language Education & 1 & 2,56 \\
\hline $\begin{array}{l}\text { Kahramanmaraş Sütçü } \\
\text { İmam University }\end{array}$ & Institute of Social Sciences & Eastern Linguistics and Literature & 1 & 2,56 \\
\hline Mersin University & Institute of Social Sciences & Department of German Language and Literature & 1 & 2,56 \\
\hline Nevşehir University & Institute of Social Sciences & Department of Turkish Language and Literature & 1 & 2,56 \\
\hline Ondokuzmayıs University & Institute of Social Sciences & Department of Turkish Language and Literature & 1 & 2,56 \\
\hline Pamukkale University & Institute of Educational Sciences & Department of Turkish Language Education & 1 & 2,56 \\
\hline Selçuk University & Institute of Educational Sciences & Department of Turkish Language Education & 1 & 2,56 \\
\hline Trakya University & Institute of Social Sciences & Department of Turkish Language and Literature & 1 & 2,56 \\
\hline Yüzüncü Yıl University & Institute of Social Sciences & Department of Basic Islamic Studies & 1 & 2,56 \\
\hline Anadolu University & Institute of Social Sciences & Department of Turkish Language and Literature & 1 & 2,56 \\
\hline
\end{tabular}


Table 7 shows at which universities and institutes master's theses were written. According to this, the universities with the highest number of master's theses are as follows: Ankara University 5, Eskişehir Osmangazi University 5, and Marmara University 4 . When the type of institutes were considered, the highest number of master's theses ( 27 theses) were found at the Institute of Social Sciences. 11 master's theses were written at the Institute of Educational Sciences, and only 1 master's thesis was written at the Institute of Science and Technology. With regard to the characteristics of the institute's master's theses that were conducted, it is remarkable that the number of theses in the Institute of Science and Technology are scarce.

When the departments where master's theses were written, are considered, the maximum number of master's theses (16 theses) were written in the Department of Turkish Language and Literature. 10 master's theses were written in the Department of Turkish Language Education and 3 master's theses were written in the Department of Linguistics. The Department of Turkish Language and Literature is clearly in the forefront in the number of master's theses in the field of lexicography. Therefore, master's theses in the field of Turkish lexicography are mostly conducted in Turkish language and literature.

Table 8: Master's theses supervisors

\begin{tabular}{lcc}
\hline Name of the Master's Theses Supervisor & Number of Theses Supervised & $\begin{array}{c}\text { Total Percentage Value of } \\
\text { Master's Theses }\end{array}$ \\
\hline Erdoğan Boz & 5 & 12.82 \\
Engin Yllmaz & 2 & 5.12 \\
Mustafa Sinan Kaçalın & 2 & 5.12 \\
Ahmet Akçataş & 1 & 2.56 \\
Ahmet Günşen & 1 & 2.56 \\
Ahmet Turan Sinan & 1 & 2.56 \\
Asuman Akay Ahmed & 1 & 2.56 \\
Avni Gözütok & 1 & 2.56 \\
Aybars Erözden & 1 & 2.56 \\
Cem Bozşahin & 1 & 2.56 \\
Dilek Ataizi & 1 & 2.56 \\
Ertuğrul Efeoğlu & 1 & 2.56 \\
Faruk Çiftçi & 1 & 2.56 \\
Fikret Turan & 1 & 2.56 \\
Günay Karaağaç & 1 & 2.56 \\
Hacer Karacan & 1 & 2.56 \\
Halil İbrahim Usta & 1 & 2.56 \\
Halit Biltekin & 1 & 2.56 \\
Hülya Kasapoğlu Çengel & 1 & 2.56 \\
İbrahim Ethem Özkan & 1 & 2.56 \\
& &
\end{tabular}




\begin{tabular}{lcc} 
Latif Beyreli & 1 & 2.56 \\
M. Faruk Toprak & 1 & 2.56 \\
M. Mehdi Ergüzel & 1 & 2.56 \\
Mehmet Gürlek & 1 & 2.56 \\
Nadir Engin Uzun & 1 & 2.56 \\
Nurettin Öztürk & 1 & 2.56 \\
Salih Demirbilek & 1 & 2.56 \\
Sila Ay & 1 & 2.56 \\
Veli Doğan Günay & 1 & 2.56 \\
Vural Ülkü & 1 & 2.56 \\
Yakup Civelek & 1 & 2.56 \\
Zehra Göre & 1 & 2.56 \\
Zeki Kaymaz & 1 & 2.56 \\
Total & 39 & $\mathbf{1 0 0 . 0 0}$ \\
\hline
\end{tabular}

33 different academics supervised 39 master's theses. Academics supervising the most master's theses are as follows: Erdoğan Boz 5, Engin Yilmaz 2, Mustafa Sinan Kaçalin 2. As regards the study area of the supervisors, it was found that the supervisors are mostly researchers in the field of Turkish language and literature. In addition, it can be seen that all of the master's theses are conducted with only one supervisor. Although the higher education system in Turkey allows more than one master's thesis supervisor, more than one supervisor was not preferred in conducting master's theses.

\subsubsection{Published oral presentations}

Table 9: Published oral presentations by year

\begin{tabular}{cccccc}
\hline Year & Frequency & $\%$ & Year & Frequency & $\%$ \\
\hline 1969 & 1 & 0.33 & 2007 & 37 & 12.29 \\
1972 & 2 & 0.66 & 2008 & 60 & 19.93 \\
1985 & 2 & 0.66 & 2009 & 36 & 11.96 \\
1999 & 9 & 2.99 & 2010 & 23 & 7.64 \\
2000 & 4 & 1.33 & 2011 & 7 & 2.33 \\
2002 & 1 & 0.33 & 2012 & 9 & 2.99 \\
2003 & 1 & 0.33 & 2013 & 25 & 8.31 \\
2004 & 8 & 2.66 & 2015 & 1 & 0.33 \\
2005 & 1 & 0.33 & 2016 & 72 & 23.92 \\
2006 & 2 & 0.66 & Total & 301 & $\mathbf{1 0 0 . 0 0}$ \\
\hline
\end{tabular}

As can be seen from the total number of published oral presentations these are one of the most produced text types compared to other text types. Table 9 shows that the oldest oral presentation in the database was presented in 1969. 
Although many scientific activities such as symposiums, conferences and congresses were held since the establishment of the Turkish Language Institute in 1932, Turkish researchers did not choose to present their studies on lexicography in the form of oral presentations. With the beginning of the 2000s, it is observed that there is an increase in the preference for oral presentations in texts related to lexicography. Although the number of presentations have increased in the last decade, in some years the number of presentations have been quite low compared to other years. One of the most important essential factors for the increasing number of presentations is lexicographic symposiums organised in Turkey in recent years.

Table 10: Frequency and percentages of published oral presentations with regard to the number of authors

\begin{tabular}{lcc}
\hline Number of authors & Frequency & $\%$ \\
\hline Single author & 273 & 90.69 \\
Two authors & 23 & 7.6 \\
Three authors & 3 & 0.99 \\
Four authors & 1 & 0.33 \\
Total & $\mathbf{3 0 1}$ & $\mathbf{1 0 0 . 0 0}$ \\
\hline
\end{tabular}

Of the published oral presentations, $273(90.69 \%)$ are by one author, $23(7.6 \%)$ are by two authors, $3(0.99 \%)$ are by three authors and $1(0.33 \%)$ is by four authors. As shown by these data, oral presentations prepared by single authors are common. The number of oral presentations with two authors are low. It can be claimed that teamwork is not preferred in these studies.

Table 11: Congresses and symposiums producing the most oral presentations

\begin{tabular}{|c|c|c|}
\hline \# & Name of the congress/symposium & $\begin{array}{l}\text { Number of } \\
\text { Presentations }\end{array}$ \\
\hline 1 & $\begin{array}{l}\text { II. Uluslararası Sözlükbilimi Sempozyumu } \\
\text { (2nd International Lexicography Symposium) }\end{array}$ & 39 \\
\hline 2 & $\begin{array}{l}\text { Uluslararası Türkiyat Araştırmaları Bilgi Şöleni Bildirileri } \\
\text { (International Symposium on Turkish Studies) }\end{array}$ & 36 \\
\hline 3 & $\begin{array}{l}\text { Uluslararası Kâşgarlı Mahmud Sempozyumu } \\
\text { (International Kashgar Mahmoud Symposium) }\end{array}$ & 34 \\
\hline 4 & $\begin{array}{l}\text { I. Uluslararası Sözlükbilimi Sempozyumu } \\
\text { (1st International Lexicography Symposium) }\end{array}$ & 29 \\
\hline 5 & $\begin{array}{l}\text { Kaşgarlı Mahmut ve Türk Dünyasının Dili, Edebiyatı, Kültürü ve Tarihi (Kashgarli } \\
\text { Mahmut and Language, Literature, Culture and History of the Turkish World) }\end{array}$ & 22 \\
\hline 6 & $\begin{array}{l}\text { Türkiye de ve Dünya da Sözlük Yazımı ve Araştırmaları Uluslararası Sempozyumu } \\
\text { (International Symposium of Dictionary Compiling and Research in Turkey and the } \\
\text { World) }\end{array}$ & 33 \\
\hline 7 & $\begin{array}{l}\text { IV. Uluslararası Türk Dili Kurultayı Bildirileri } \\
\text { (4th International Turkish Language Congress) }\end{array}$ & 21 \\
\hline
\end{tabular}


Papers on lexicography were presented in 301 different categories. The reason why the categories were so diverse was that papers on lexicography were presented in symposiums related to grammar and linguistics in the years before 2014. Before the 2000s, symposiums exclusively on lexicography were almost none. The First International Lexicography Symposium was held by Sakarya University on 26-27 November, 2014. The Second was held by İstanbul University on 3-4 November, 2015, and the Third was held on 3-4 November 2016 by Eskişehir Osmangazi University. Since then, it has been decided to organise the Lexicography Symposium every two years. These symposiums have increased the number of oral presentations on lexicography in Turkey.

\subsubsection{News}

News is a type of text including neologism examples, suggestions for foreign words and/or promotions of new publications about lexicography/dictionaries. News is published in the Journal of the Turkish Language Association.

Table 12: News by year

\begin{tabular}{cccccc}
\hline Year & Frequency & $\%$ & Year & Frequency & $\%$ \\
\hline 1952 & 1 & 4.76 & 1999 & 2 & 9.52 \\
1953 & 1 & 4.76 & 2004 & 1 & 4.76 \\
1959 & 2 & 9.52 & 2007 & 2 & 9.52 \\
1960 & 1 & 4.76 & 2009 & 1 & 4.76 \\
1962 & 1 & 4.76 & 2011 & 2 & 9.52 \\
1971 & 1 & 4.76 & 2012 & 2 & 9.52 \\
1987 & 1 & 4.76 & 2013 & 1 & 4.76 \\
1989 & 1 & 4.76 & 2014 & 1 & 4.76 \\
\end{tabular}


The number of news items related to lexicography are produced irregularly by year. News text type is published annually. However, it is insignificant numerically for this study.

\subsubsection{Books}

Table 13: Books by year

\begin{tabular}{lcc}
\hline Year & Frequency & $\%$ \\
\hline 2007 & 1 & 33.3 \\
2011 & 1 & 33.3 \\
2016 & 1 & 33.3 \\
Total & $\mathbf{3}$ & $\mathbf{1 0 0 . 0 0}$ \\
\hline
\end{tabular}

In the field of Turkish lexicography, the number of books are insufficient. There is still no lexicographic handbook on Turkish lexicography, such as those by Atkins and Rundell 2008, Durkin 2016, Jackson 2013, Svensén 2009, or Zgusta 1971.

\subsubsection{Articles}

Table 14: Articles by year

\begin{tabular}{ccccccccc}
\hline Year & Frequency & $\%$ & Year & Frequency & $\%$ & Year & Frequency & $\%$ \\
\hline 1934 & 1 & 0.21 & 1974 & 1 & 0.21 & 2001 & 4 & 0.84 \\
1939 & 1 & 0.21 & 1977 & 1 & 0.21 & 2002 & 11 & 2.32 \\
1942 & 1 & 0.21 & 1981 & 1 & 0.21 & 2003 & 6 & 1.26 \\
1952 & 1 & 0.21 & 1983 & 1 & 0.21 & 2004 & 11 & 2.32 \\
1953 & 2 & 0.42 & 1984 & 1 & 0.21 & 2005 & 5 & 1.05 \\
1954 & 1 & 0.21 & 1986 & 2 & 0.42 & 2006 & 14 & 2.95 \\
1956 & 1 & 0.21 & 1987 & 1 & 0.21 & 2007 & 14 & 2.95 \\
1957 & 1 & 0.21 & 1990 & 1 & 0.21 & 2008 & 18 & 3.79 \\
1959 & 1 & 0.21 & 1991 & 2 & 0.42 & 2009 & 64 & 13.47 \\
1960 & 1 & 0.21 & 1994 & 3 & 0.63 & 2010 & 22 & 4.63 \\
1961 & 1 & 0.21 & 1995 & 3 & 0.63 & 2011 & 46 & 9.68 \\
1965 & 1 & 0.21 & 1996 & 3 & 0.63 & 2012 & 24 & 5.05 \\
1970 & 1 & 0.21 & 1997 & 4 & 0.84 & 2013 & 36 & 7.58 \\
1971 & 2 & 0.42 & 1998 & 15 & 3.16 & 2014 & 39 & 8.21 \\
1972 & 9 & 1.89 & 1999 & 16 & 3.37 & 2015 & 48 & 10.11 \\
1973 & 1 & 0.21 & 2000 & 9 & 1.89 & 2016 & 23 & 4.84 \\
& & & Total & & & & 475 & $\mathbf{1 0 0 . 0 0}$ \\
\hline
\end{tabular}


As can be seen in Table 14, the most produced text type in the field of Turkish lexicography is articles. The ratio of the total text type of the articles among the types of texts produced in this area is $47.4 \%$. 475 articles were produced in a total of 48 years. In the field of Turkish lexicography, an average of 9.8 articles is produced annually. The number of articles have shown an upward trend in the last 10 years. The year the most articles (64 articles) were published is 2009, followed by 2011 (46 articles). When the years are taken into consideration, there is a marked increase towards the present.

Table 15: Frequency and percentage of the number of authors

\begin{tabular}{lcc}
\hline Number of authors & Frequency & $\%$ \\
\hline Single author & 437 & 92 \\
Two authors & 36 & 7.57 \\
Three authors & 2 & 0.42 \\
\multicolumn{1}{c}{ Total } & $\mathbf{4 7 5}$ & $\mathbf{1 0 0 . 0 0}$ \\
\hline
\end{tabular}

Table 15 provides information on the number of authors. Of the articles in the database, $437(92 \%)$ are by single authors, $36(7.57 \%)$ are by two authors, and $2(0.42 \%)$ are by three authors. Contrary to published oral presentations, there are no articles by 4 authors in Turkish lexicography. The number of articles by multiple authors are close to the number of oral presentations. As shown by these data, the studies with multiple authors in the field of Turkish lexicography are mainly composed by two authors. It can be said that articles prepared as teamwork are not much preferred.

In Turkey journal publishing only in the field of lexicography has not been realized yet. Articles related to lexicography are published in academic journals on linguistics and grammar research.

Table 16: Academic journals publishing the most articles in the field of lexicography and the number of articles published

\begin{tabular}{lcc}
\hline Name of the journal & Published Number of Articles & $\%$ \\
\hline Turkish Studies & 124 & 26.1 \\
Türk Dili Dil ve Edebiyat Dergisi & 73 & 15.3 \\
Kebikeç Dergisi & 28 & 5.8 \\
Littera Turca & 28 & 5.8 \\
Dil ve Edebiyat Araştırmaları Dergisi & 24 & 5.1 \\
Ankara Üniversitesi Dil ve Tarih Coğrafya & 15 & 3.1 \\
Fakültesi Dergisi & & 2.9 \\
International Journal of Language Academy & 14 &
\end{tabular}




$\begin{array}{lcc}\text { Selçuk Üniversitesi Türkiyat Araştırmaları } & 12 & 2.5 \\ \text { Dergisi } & & \\ \text { Uluslararası TEKE Dergisi } & 11 & 2.3 \\ \text { Ankara Üniversitesi Türkiyat Araştırmaları } & 9 & 1.8 \\ \text { Enstitüsü Dergisi } & & 1.6 \\ \text { Belleten } & 8 & 1.6 \\ \text { Türk Dünyası Dil ve Edebiyat Dergisi } & 8 & 1.6 \\ \text { Türkbilig Türkoloji Araştırmaları Dergisi } & 8 & 1.4 \\ \text { Diyalektolog } & 7 & 1.2 \\ \text { Ege Üniversitesi Türk Dünyası İncelemeleri } & 6 & 1.2 \\ \text { Dergisi } & & 1.2 \\ \text { Millî Folklor Dergisi } & 6 & 1.2 \\ \text { Türklük Bilimi Araştırmaları Dergisi } & 6 & 0.8 \\ \text { Türük Dergisi } & 6 & \\ \text { İstanbul Üniversitesi Türk Dili ve Edebiyatı } & 5 & \\ \text { Dergisi } & & \\ \text { Bilig Türk Dünyası Sosyal Bilimler Dergisi } & 4 & \end{array}$

Table 16 shows the first 20 journals in which articles related to Turkish lexicography are published, and the number of articles related to lexicography published in these journals, and their ratio to the total number of journals.

The total number of journals in the database of the study which published articles in the field of lexicography are 76 . Of the 475 articles in the database, 402 were published by the first 20 journals shown in the table. The journals with the highest number of articles on Turkish lexicography are as follows: 1 . Turkish Studies: 124 articles, 2. Türk Dili Dil ve Edebiyat Dergisi (Turkish Language and Literature Journal): 73 articles, 3. Kebikeç Dergisi (Kebikeç Journal): 28 articles.

Out of 31 journals, especially those issued by social science institutes in Turkey (e.g. Kahramanmaraş Sütçü Imam University Journal of Social Sciences, Eskişehir Osmangazi University Journal of Social Sciences, Istanbul University Journal of Social Sciences), only one journal published an article on lexicography.

\subsubsection{Reviews}

Newly published dictionaries are generally introduced in texts in the review category.

Table 17: Reviews by year

\begin{tabular}{ccccccccc}
\hline Year & Frequency & $\%$ & Year & Frequency & $\%$ & Year & Frequency & $\%$ \\
\hline 1935 & 2 & 1.33 & 1975 & 13 & 8.67 & 2002 & 6 & 4.00 \\
1936 & 3 & 2.00 & 1976 & 5 & 3.33 & 2003 & 1 & 0.67 \\
1939 & 1 & 0.67 & 1977 & 5 & 3.33 & 2004 & 2 & 1.33
\end{tabular}




\begin{tabular}{|c|c|c|c|c|c|c|c|c|}
\hline 1954 & 5 & 3.33 & 1979 & 1 & 0.67 & 2005 & 5 & 3.33 \\
\hline 1956 & 1 & 0.67 & 1980 & 2 & 1.33 & 2006 & 3 & 2.00 \\
\hline 1960 & 1 & 0.67 & 1981 & 1 & 0.67 & 2007 & 2 & 1.33 \\
\hline 1962 & 1 & 0.67 & 1982 & 3 & 2.00 & 2008 & 5 & 3.33 \\
\hline 1963 & 1 & 0.67 & 1991 & 2 & 1.33 & 2009 & 5 & 3.33 \\
\hline 1965 & 1 & 0.67 & 1992 & 1 & 0.67 & 2010 & 7 & 4.67 \\
\hline 1967 & 2 & 1.33 & 1994 & 2 & 1.33 & 2011 & 6 & 4.00 \\
\hline 1968 & 1 & 0.67 & 1995 & 5 & 3.33 & 2012 & 6 & 4.00 \\
\hline 1969 & 1 & 0.67 & 1996 & 5 & 3.33 & 2013 & 3 & 2.00 \\
\hline 1971 & 1 & 0.67 & 1999 & 4 & 2.67 & 2014 & 10 & 6.67 \\
\hline 1972 & 6 & 4.00 & 2000 & 2 & 1.33 & 2015 & 7 & 4.67 \\
\hline 1973 & 1 & 0.67 & 2001 & 1 & 0.67 & 2016 & 1 & 0.67 \\
\hline 1974 & 1 & 0.67 & \multicolumn{4}{|c|}{ Total } & 150 & 100.00 \\
\hline
\end{tabular}

Ordered by year, the number of reviews are close to each other. Although the number of reviews have increased for some years, they continue with an average number of $3.2 \%$. When the number of dictionaries published between the years 1935 and 2016 in Turkey are considered, it is remarkable that there are so few reviews.

\subsection{Researchers and citations}

In this section, the quantitative status of the authors contributing to lexicography and the citations of these authors' works in the database of the current study are discussed.

\subsubsection{The contributors, and their contributions}

The programs in which the doctoral dissertations and master's theses are written have been mentioned above. Graduate theses are mostly conducted in the Turkish language and literature departments. Among the lexicographers who produced the most texts, we see the names of those who are supervisors of master's theses and doctoral dissertations.

Table 18: Most productive researchers

\begin{tabular}{|c|c|c|c|c|c|c|c|c|c|}
\hline$\#$ & Name of researcher & 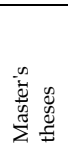 & 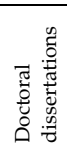 & 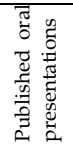 & ż & $\begin{array}{l}\text { मै } \\
\frac{8}{8} \\
0\end{array}$ & $\frac{\mathscr{g}}{\frac{0}{Z}}$ & 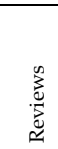 & 胥 \\
\hline 1. & Erdoğan Boz & & & 10 & & 1 & 13 & & 24 \\
\hline 2. & Turkish Language Institute & & & & 6 & & & 14 & 20 \\
\hline 3. & Tuncer Gülensoy & & & 4 & & & 3 & 5 & 12 \\
\hline
\end{tabular}




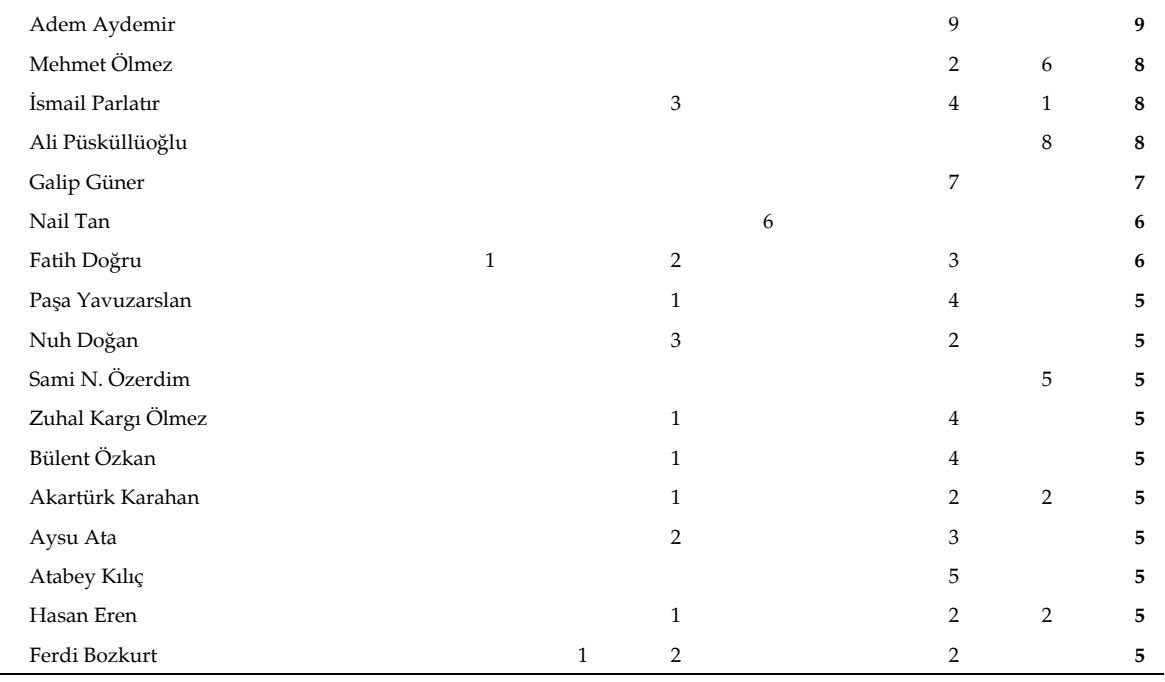

The twenty researchers who are the most productive in Turkish lexicography are shown in Table 18. In the database of the current study, there are 678 researchers who produced texts related to Turkish lexicography. The ratio of the total number of texts to the number of researchers is $1.4 \%$. The three most productive researchers in Turkish lexicography are Erdoğan Boz, the Turkish Language Association (studies related to this lexicographic association are sometimes published under the corporate name) and Tuncer Gülensoy. The first 20 researchers produced the most texts: $15.7 \%$ of the total texts. The authors who published the most articles are Erdoğan Boz (13 articles), Adem Aydemir (7 articles) and Galip Güner ( 7 articles). The authors who published the most oral presentations are Erdoğan Boz (10 papers), Tuncer Gülensoy (3 papers), Nuh Doğan and İsmail Parlatır (3 papers each).

When the different types of writing characteristics of researchers related to lexicography are considered, another remarkable fact emerges. There is no researcher who has produced texts in all text types: master theses, doctoral dissertations, published oral presentations, news, books, articles and reviews. Erdoğan Boz, Ferdi Bozkurt and Fatih Doğru were each responsible for three different text types.

\subsubsection{Most highly cited publications}

As mentioned above, the total number of journals that are in the Turkish Lexicography Corpus database and that publish articles in the field of lexicology are 76. However, among these journals, only the Bilig Journal of Turkish World Social Sciences and National Folklore are indexed in the Science Citation Index. Only 4 articles in the database created for Turkish lexicography were published in this journal. The remaining journals are indexed in international databases/ 
resources such as EBSCO, MLA and INDEX COPERNICUS, and in national databases/resources such as ULAKBIM and ARASTIRMAX, while some journals are not indexed in any databases/resources at all. In this study, citation data are obtained from Google Scholar.

\subsubsection{Doctoral dissertations}

Table 19: The most cited doctoral dissertations

\begin{tabular}{|c|c|c|c|c|c|}
\hline \# & Author & Year & Text & $\begin{array}{c}\text { Total } \\
\text { citations }\end{array}$ & $\begin{array}{l}\text { Percentage of } \\
\text { total citations }\end{array}$ \\
\hline 1. & Ahmet Hilmi İmamoğlu & 1993 & $\begin{array}{l}\text { Farsça-Türkçe manzum sözlükler ve Şahidi'nin } \\
\text { Sözlügü (inceleme-metin) }\end{array}$ & 6 & 37.50 \\
\hline 2. & Ahmet Dönger & 2009 & $\begin{array}{l}\text { Sözlük Kullanma Eğitiminin Yabancı Dil Olarak } \\
\text { Almanca Öğrenimine Etkisi }\end{array}$ & 3 & 18.75 \\
\hline 3. & Özer Şenödeyici & 2011 & $\begin{array}{l}\text { Naili Divanı Sözlüğü (Bağlamlı Dizin ve İşlevsel } \\
\text { Sözlük) }\end{array}$ & 3 & 12.50 \\
\hline 4. & Furkan Öztürk & 2007 & $\begin{array}{l}\text { Bakî Divanı Sözlüğü (Bağlamlı Dizin ve İşlevsel } \\
\text { Sözlük) }\end{array}$ & 2 & 12.50 \\
\hline 5. & Resul Özavşar & 2013 & $\begin{array}{l}\text { Tarama Sözlüğü ve Türkçe Sözlük'e Göre Anlam } \\
\text { Değişmeleri }\end{array}$ & 1 & 6.25 \\
\hline 6. & Dilek Herkmen & 2009 & Dîvânü Lugati't-Türk'te Fiil Yapımı & 1 & 6.25 \\
\hline
\end{tabular}

Only 6 of the 12 doctoral dissertations have been cited, 6 doctoral dissertations having received a total of 16 citations. The most cited dissertation is FarsçaTürkçe Manzum Sözlükler ve Şahidi'nin Sözlüğü (inceleme-metin) (Persian-Turkish Poetry Dictionaries and the Dictionary of Shahidi) (examination-text)).

\subsubsection{Master's theses}

Table 20: The most cited master's theses

\begin{tabular}{|c|c|c|c|c|c|}
\hline \# & Author & Year & Text & $\begin{array}{c}\text { Total } \\
\text { citations }\end{array}$ & $\begin{array}{l}\text { Percentage of } \\
\text { total citations }\end{array}$ \\
\hline 1. & Emrah Özcan & 2006 & $\begin{array}{l}\text { Başlangıç Düzeyi Yabancı Dil Olarak } \\
\text { Türkçe Öğretimi için Sözlükçe } \\
\text { Çalışması }\end{array}$ & 8 & 12.6 \\
\hline 2. & Burak İbrahim Sevindi & 2013 & $\begin{array}{l}\text { Türkçe Metinlerde Denetimli ve Sözlük } \\
\text { Tabanlı Duygu Analizi Yaklaşımlarının } \\
\text { Karşılaştırılması }\end{array}$ & 7 & 11.1 \\
\hline 3. & Bilge Gökter & 2010 & $\begin{array}{l}\text { Sözlükbilim Temelinde Türkiye'de Ağız } \\
\text { Sözlükçülüğü (İlke ve Yöntemler) }\end{array}$ & 5 & 7.9 \\
\hline 4. & Ziya Doğan Koreli & 2007 & $\begin{array}{l}\text { Eylem ve Ad Olarak Kullanılan ve } \\
\text { Türkçe Sözlükte Bulunmayan Öbekler } \\
\text { ve Bunların Türkçenin Yabancı Dil } \\
\text { Olarak Öğretimindeki Yeri }\end{array}$ & 5 & 7.9 \\
\hline
\end{tabular}




\begin{tabular}{|c|c|c|c|c|c|}
\hline 5. & Ceren Oğuz & 2011 & $\begin{array}{l}\text { Kâmüs-1 Türkî'den Türkçe Sözlük'e } \\
\text { Anlam Değişmeleri: Adlar (K-Z) }\end{array}$ & 5 & 7.9 \\
\hline 6. & Fatih Doğru & 2012 & $\begin{array}{l}\text { Kâmüs-1 Türkî`den Türkçe Sözlük'e } \\
\text { Anlam Değişmeleri: Eylemler }\end{array}$ & 5 & 7.9 \\
\hline 7. & İlke Küçük & 2012 & $\begin{array}{l}\text { Kâmüs-1 Türkî'den Türkçe Sözlüğe } \\
\text { Anlam Değişmeleri- Adlar (A-K) }\end{array}$ & 5 & 7.9 \\
\hline 8. & Ceren Berber & 2012 & $\begin{array}{l}\text { Türkçenin Yabancı Dil Olarak } \\
\text { Öğretiminde Yardımcı Kaynak } \\
\text { Hazırlama: Sözlük Modeli Önçalışması }\end{array}$ & 3 & 4.7 \\
\hline 9. & Musa Salan & 2010 & $\begin{array}{l}\text { Et-Tuhfetü'z -Zekiyye Fi'l-Lugāti't- } \\
\text { Türkiyye'de Fiil }\end{array}$ & 3 & 4.7 \\
\hline 10. & Necati Kaya & 2007 & $\begin{array}{l}\text { Okul Sözlüklerinin Değerlendirilmesi } \\
(1945-2005)\end{array}$ & 3 & 4.7 \\
\hline 11. & Hatice Korkmaz & 2007 & $\begin{array}{l}\text { Divanu Lugati't Türk'teki Atasözlerinin } \\
\text { Anlambilimsel Açıdan İncelenmesi }\end{array}$ & 3 & 4.7 \\
\hline 12. & Mehmet Nuri Alpak & 2006 & $\begin{array}{l}\text { Arap Dilinde Sözlük Çalışmaları ve } \\
\text { Nazım Efendi'nin Tercümanu'l-Lügat } \\
\text { Adlı Eserinin İncelenmesi }\end{array}$ & 3 & 4.7 \\
\hline 13. & Ali Çiçek & 1997 & $\begin{array}{l}1928 \text { tarihine kadar yazılmış Fransızca- } \\
\text { Türkçe, Türkçe-Fransızca ve çok dilli } \\
\text { sözlükler üzerine bir dil araşırması }\end{array}$ & 2 & 3.1 \\
\hline 14. & Selim Tiryakiol & 2013 & $\begin{array}{l}\text { Dil Öğretimi Geleneğimizde Manzum } \\
\text { Sözlükler (Tuhfe-i Asım Örneği) }\end{array}$ & 2 & 3.1 \\
\hline 15. & Serper Acar & 2009 & $\begin{array}{l}\text { Necati Bey Divanı Sözlüğü (Bağlamlı } \\
\text { Dizin Ve İşlevsel Sözlük) }\end{array}$ & 2 & 3.1 \\
\hline 16. & Efsun Bilgin & 2015 & $\begin{array}{l}\text { Türkçe Sözlük'te Özel Ad Kaynaklı } \\
\text { Sözler }\end{array}$ & 1 & 1.5 \\
\hline 17. & Pervin Sayan & 2005 & $\begin{array}{l}\text { 11-14 Yaş İçin Hazırlanan Okul } \\
\text { Sözlüklerinde Tanımlar Üzerine Bir } \\
\text { Araştırma }\end{array}$ & 1 & 1.5 \\
\hline
\end{tabular}

22 of the 39 master's theses have never received any citations, while 17 master's theses have received a total of 63 citations. The most cited master's thesis is Başlangıç Düzeyi Yabancı Dil Olarak Türkçe Öğretimi için Sözlükçe Çalışması (A Glossary Study for Teaching Turkish as a Foreign Language) written by Emrah Özcan.

\subsubsection{Articles}

Table 21: The 30 most cited articles

\begin{tabular}{llllcc}
\hline$\#$ & Author & Year & Text & $\begin{array}{c}\text { Total } \\
\text { citations }\end{array}$ & $\begin{array}{c}\text { Ratio of } \\
\text { citations to total } \\
\text { citations }\end{array}$ \\
\hline 1. & Ali Göçer & 2009 & $\begin{array}{l}\text { Türkçe Eğitiminde Öğrencilerin Söz } \\
\text { Varlığını Geliştirme Etkinlikleri ve } \\
\text { Sözlük Kullanımı }\end{array}$ & 51 & $3.62 \%$ \\
\cline { 3 - 5 } 2. & Ahmet Kocaman & Dilbilim, Sözlük, Sözlükçülük & 41 & $2.91 \%$ \\
\cline { 3 - 5 } 3. & Atabey Kılıç & 2007 & $\begin{array}{l}\text { Türkçe-Farsça Manzum } \\
\text { Sözlüklerden Tuhfe-i Vehbì (Metin) }\end{array}$ & 33 & $2.34 \%$ \\
\cline { 3 - 5 } & & &
\end{tabular}




\begin{tabular}{|c|c|c|c|c|c|}
\hline 4. & Nurettin Demir & 1999 & Ağız Sözlükçülüğğu & 24 & $1.70 \%$ \\
\hline 5. & Deniz Melanlıŏ̆lu & 2013 & $\begin{array}{l}\text { Ortaokul Öğrencilerinin Sözlük } \\
\text { Kullanma Alışkanlıkları: Nitel Bir } \\
\text { Araştırma }\end{array}$ & 22 & $1.56 \%$ \\
\hline 6. & Paşa Yavuzarslan & 2004 & $\begin{array}{l}\text { Türk Sözlükçülük Geleneği } \\
\text { Açısından Osmanlı Dönemi } \\
\text { Sözlükleri Ve Şemseddin Sâmîn nin } \\
\text { Kâmüs-1 Türkî'si }\end{array}$ & 22 & $1.56 \%$ \\
\hline 7. & Gülsel Sev & 2004 & Divanü Lugatit Türk'te İkilemeler & 21 & $1.49 \%$ \\
\hline 8. & Havva Yaman & 2010 & $\begin{array}{l}\text { İlköğretim İkinci Kademe } \\
\text { Öğrencilerinin Sözlük Kullanma } \\
\text { Alışkanlıkları Üzerine Bir } \\
\text { Değerlendirme }\end{array}$ & 21 & $1.49 \%$ \\
\hline 9. & Doğan Aksan & 1998 & $\begin{array}{l}\text { Türklerde Sözlükçülük, Bugün } \\
\text { Türkiye'de Sözlük }\end{array}$ & 19 & $1.35 \%$ \\
\hline 10. & Nadir İlhan & 2009 & $\begin{array}{l}\text { Sözlük Hazırlama İlkeleri, Çeşitleri } \\
\text { ve Özellikleri }\end{array}$ & 19 & $1.35 \%$ \\
\hline 11. & Ali Göçer & 2010 & $\begin{array}{l}\text { Türk Dili ile İlgili Sözlüklere Genel } \\
\text { Bir Bakış Günümüz İlköğretim } \\
\text { Sözlükleri }\end{array}$ & 18 & $1.28 \%$ \\
\hline 12. & Şükrü Haluk Akalın & 2010 & Sözcük Bilimi ve Sözlükçülük & 18 & $1.28 \%$ \\
\hline 13. & Zeynep Korkmaz & 2000 & Türkiye'de Ağız Sözlükleri & 18 & $1.28 \%$ \\
\hline 14. & Zeynep Korkmaz & 2000 & Türkiye'de Ağız Sözlükleri & 18 & $1.28 \%$ \\
\hline 15. & Özen Yaylagül & 2010 & $\begin{array}{l}\text { Divanu Lugati't-Türk'te Yer Alan } \\
\text { Atasözlerindeki Metaforlar }\end{array}$ & 17 & $1.20 \%$ \\
\hline 16. & Zekeriya Bingöl & 2006 & $\begin{array}{l}\text { Sözlük ve Sözlükçülük Üzerine Bir } \\
\text { Araştırma }\end{array}$ & 17 & $1.20 \%$ \\
\hline 17. & Kerime Üstünova & 1998 & $\begin{array}{l}\text { Dede Korkut Destanlarında İki } \\
\text { Sözcüklü Yüklemler }\end{array}$ & 16 & $1.13 \%$ \\
\hline 18. & Bayram Çetinkaya & 2009 & Eşdizimli Sözlükler & 13 & $0.92 \%$ \\
\hline 19. & Harun Tolasa & 1986 & $\begin{array}{l}\text { 18. yy'da Yazılmış Bir Divan } \\
\text { Edebiyatı Terimleri Sözlüğü } \\
\text { Müstakimzade`nin Istılahatü'ş- } \\
\text { Şi'riye'si }\end{array}$ & 13 & $0.92 \%$ \\
\hline 20. & Süer Eker & 2009 & $\begin{array}{l}\text { Divanu Lugati't-Türk ve İran } \\
\text { Dillerinden Kopyalar Üzerine I }\end{array}$ & 13 & $0.92 \%$ \\
\hline
\end{tabular}

Table 21 shows the 20 most cited articles in Turkish lexicography. All 475 articles have received a total of 1406 citations. 238 articles haven't been cited, while 237 articles have been cited. 46 articles have received only 1 citation. When the total number of citations to articles are divided by the number of cited articles, the average number of citations are 5.06. When the total number of citations are divided by the number of all articles in the database, the average number of articles are 2.70. The most cited article is "Türkçe Eğitiminde Öğrencilerin Söz Varlığını Geliştirme Etkinlikleri ve Sözlük Kullanımı" ("Activities for Developing 
the Vocabulary and Dictionary Usage of Students in Turkish Education") by Ali Göçer.

Table 22: Dispersion of the 30 most cited articles by the year produced

\begin{tabular}{cccc}
\hline $\begin{array}{c}\text { Year of publication of } \\
\text { articles }\end{array}$ & Number of articles & $\begin{array}{c}\text { Number of citations } \\
2009\end{array}$ & $\begin{array}{c}\text { Year ratio by number of } \\
\text { articles }\end{array}$ \\
1998 & 7 & 132 & 18,8 \\
2010 & 4 & 88 & 22 \\
2000 & 5 & 86 & 17,2 \\
2004 & 3 & 48 & 16 \\
2013 & 2 & 43 & 21,5 \\
2007 & 2 & 34 & 17 \\
2002 & 1 & 33 & 33 \\
1999 & 2 & 25 & 12,5 \\
2006 & 1 & 24 & 24 \\
1986 & 1 & 17 & 17 \\
1970 & 1 & 13 & 13 \\
2003 & 1 & 12 & 12 \\
2005 & 1 & 12 & 12 \\
2012 & 1 & 12 & 12 \\
\hline
\end{tabular}

Table 22 shows the number of the most cited articles and their publication years. When the publication years of the articles are considered, the articles published in 2009 were cited most, followed by those of the years 1998 and 2010.

\subsubsection{Academic journals}

Table 23: The number of citations of the journals

\begin{tabular}{clcc}
\hline$\#$ & Name of journal & Number of citations & Ratio of citations to total citations \\
\hline 1. & Turkish Studies Language/Literature & 356 & $25.32 \%$ \\
2. & Türk Dili Dil ve Edebiyat Dergisi & 196 & $13.94 \%$ \\
3. & Kebikeç İnsan Bilimleri için Kaynak & 164 & $11.66 \%$ \\
& Araştırmaları Dergisi & & \\
4. & Ankara Üniversitesi Dil ve Tarih-Coğrafya & 83 & $5.90 \%$ \\
& Fakültesi Türkoloji Dergisi & 54 & $3.84 \%$ \\
5. & Türklük Bilimi Araştırmalar Dergisi-TÜBAR & 51 & $2.91 \%$
\end{tabular}




\begin{tabular}{|c|c|c|c|}
\hline 7. & Millî Folklor Dergisi & 29 & $2.06 \%$ \\
\hline 8. & Uluslararası Türkçe Edebiyat Kültür Eğitim & 28 & $1.99 \%$ \\
\hline 9. & A.Ü. Türkiyat Araştırmaları Enstitüsü Dergisi & 28 & $1.99 \%$ \\
\hline 10. & Diyalektolog & 27 & $1.92 \%$ \\
\hline 11. & Dil Araştırmaları & 26 & $1.84 \%$ \\
\hline 12. & Central Asian Studies & 25 & $1.77 \%$ \\
\hline 13. & Dil ve Edebiyat Araştırmaları Dergisi & 25 & $1.77 \%$ \\
\hline 14. & Bilig Türk Dünyası Sosyal Bilimler Dergisi & 22 & $1.56 \%$ \\
\hline 15. & Modern Türklük Araştırmaları Dergisi & 19 & $1.35 \%$ \\
\hline 16. & International Journal of Language Academy & 19 & $1.35 \%$ \\
\hline 17. & Zeitschrift für die Welt der Türken & 17 & $1.20 \%$ \\
\hline 18. & $\begin{array}{l}\text { İstanbul Üniversitesi Türk Dili ve Edebiyat1 } \\
\text { Dergisi }\end{array}$ & 16 & $1.13 \%$ \\
\hline 19. & Türkbilig Türkoloji Araştırmaları Dergisi & 13 & $0.92 \%$ \\
\hline 20. & Firat Üniversitesi Sosyal Bilimler Dergisi & 13 & $0.92 \%$ \\
\hline
\end{tabular}

The table above shows the most frequently cited journals dealing with Turkish lexicography. 475 articles in the database have been published in 76 different journals. The articles in the journals have received a total of 1406 citations. Of the 474 articles in the study, 238 haven't received any citations, while 236 have been cited. Accordingly, in Turkish lexicography the most effective academic journals in terms of citation are Turkish Studies, Türk Dili Dil ve Edebiyat Dergisi (Turkish Language and Literature Journal), and Kebikeç Inssan Bilimleri için Kaynak Araştırmaları Dergisi (Kebikeç Journal of Human Resources Research).

\section{Conclusion}

For this bibliometric study, a database of 1001 texts produced between 1932 and 2016 in the field of Turkish lexicography has been created. Important information about the characteristics of the texts in the database has been put forward. The ratio of texts produced in these fields by type, their distribution by year, the distribution of doctoral dissertations and master's theses by year and institute, and the distribution of researchers supervising these studies have been indicated. In addition, the researchers producing the most texts in the field of lexicography, the degree of collaboration among the authors, institutions producing the most texts in the field of lexicography, the number of personal citations, diversity of authors' text production, and the most cited texts have been specified. Information such as which academic journals are more effective and which scientific activities include the most texts about lexicography have been indicated.

One of the general and most important results is that there has been an increase in nearly all text types in recent years. Researchers have given more space to studies on lexicography. One of the biggest problems regarding Turkish lexicography is the lack of books on theoretical lexicography. 
Another important deficiency is the lack of collaborative texts produced by researchers in this field. Projects undertaken by multiple authors as teamwork may increase the number of lexicographic texts.

A general remark can be the scarcity of doctoral dissertations, the writing of which is a longer and more extensive process than that required for the master's degree, and whose academic quality is important. That the number of symposiums that are the meeting place of researchers giving oral presentations have increased is a positive development. The symposium environments bring together researchers who work in the field of lexicography and make positive contributions to it. In addition, the published conference proceedings resulting from these symposiums bring together the texts related to the field, increase the accessibility of the texts and awareness of the researchers.

In Turkey, there is no academic journal publishing articles that discuss issues related only to lexicography. When the number of articles are considered, it can be concluded that there are enough articles for publishing an academic journal in the Turkish language exclusively on lexicography. The existence of a journal that publishes only on lexicography will provide a common platform for researchers and will facilitate access to related articles.

\section{Acknowledgements}

The texts used in the current study were created by utilizing the list of openaccess texts given on the website of the project funded by the Scientific Research Projects Coordination Unit of Eskişehir Osmangazi University (http://tsd.ogu. edu.tr/index.php?s=yayinlar). The author of this study also belongs to the researchers of the project (Project number 2016-019056).

\section{Endnotes}

1. https://ulakbim.tubitak.gov.tr/ accessed February 2, 2019.

2. https://scholar.google.com.tr accessed February 2, 2019.

3. http://web.a.ebscohost.com/ehost/search/basic?vid=0\&sid=e97c426e-c7c7-4ee5-a9c1-bd6f8 d1b1129\%40sessionmgr4008 accessed March 2, 2019.

4. http://www.toplukatalog.gov.tr/ accessed May 2, 2019.

5. https://kasif.mkutup.gov.tr/ accessed February 22, 2019.

6. https://tez.yok.gov.tr/UlusalTezMerkezi/ accessed February 4, 2019.

7. https://www.proquest.com/products-services/pqdtglobal.html accessed January 7, 2019.

\section{References}

Arik, E. 2015. A Bibliometric Analysis of Linguistics in Web of Science. Journal of Scientometric Research 4(1): 20-28.

Atkins, B.T.S. and M. Rundell. 2008. The Oxford Guide to Practical Lexicography: Oxford/New York: Oxford University Press. 
Bergenholtz, H. and R.H. Gouws. 2012. What is Lexicography? Lexikos 22: 31-42.

Day, R.A. and B. Gastel. 1995. How to Write and Publish a Scientific Paper. Fourth edition. Cambridge: Cambridge University Press.

De Schryver, G.-M. 2009a. Bibliometrics in Lexicography. International Journal of Lexicography 22(4): 423-465.

De Schryver, G.-M. 2009b. Lexikos at Eighteen: An Analysis. Lexikos 19: 372-403.

Dilaçar, A. 1953. Türkiye Türkçesi Sözlüklerinden Seçme Eserler. Türk Dili 22: 677-680.

Durkin, P. (Ed.). 2016. The Oxford Handbook of Lexicography. New York: Oxford University Press.

Eminoğlu, E. 2010. Türk dilinin sözlükleri ve sözlükçülü̈k kaynakçası. Vol. 1. Sivas: Asitan Yayıncılık.

Ercilasun, A.B. and Z. Akkoyunlu. 2014. Kâş̧garlı Mahmud Dîvânu Lugâti't-Türk Giriş-Metin-ÇeviriNotlar-Dizin. Ankara: Türk Dil Kurumu Yayınları.

Garfield, E. 1955. Citation Indexes for Science. Science 122(3159): 108-111.

Gökçe, A. 1998. Türkiye Türkçesinin tarihî sözlükleri. Volume 6. Ankara: Kebikeç Yayınları.

Hulme, E.W. 1923. Statistical Bibliography in Relation to the Growth of Modern Civilization. Two Lectures Delivered at the University of Cambridge in May, 1922.

Jackson, H. 2013. Lexicography: An Introduction. London: Routledge.

Kotan, H. 2017. Erzurum Yazma Eserler Kütüphanesinde Bulunan El Yazması Sözlükler. Atatürk Üniversitesi Sosyal Bilimler Enstitüsü Dergisi 21(4): 1491-1509.

Landau, S.I. 1984. Dictionaries: The Art and Craft of Lexicography: New York: The Scribner Press.

Lei, L. and S. Liao. 2017. Publications in Linguistics Journals from Mainland China, Hong Kong, Taiwan, and Macau (2003-2012): A Bibliometric Analysis. Journal of Quantitative Linguistics 24(1): 54-64.

Lei, L. and D. Liu. 2018. Research Trends in Applied Linguistics from 2005 to 2016: A Bibliometric Analysis and its Implications. Applied Linguistics 40(3): 540-561.

Mohsen, M.A., H.-Z. Fu and Y.-S. Ho. 2017. A Bibliometric Analysis of Linguistics Publications in the Web of Science. Journal of Scientometric Research 6(2): 109-118.

Parlatır, İ. 1995. Türkçe Sözlük Çalışmaları ve Sorunlarımız. Türk Dili Dil ve Edebiyat Dergisi 517: 3-19.

Potter, W.G. 1981. Introduction. Library Trends 30(1): 5-7.

Pritchard, A. 1969. Statistical Bibliography or Bibliometrics. Journal of Documentation 25(4): 348-349.

Svensén, B. 2009. A Handbook of Lexicography: The Theory and Practice of Dictionary-Making. Cambridge: Cambridge University Press.

Tarp, S. 2012. Do We Need a (New) Theory of Lexicography? Lexikos 22: 321-332.

Yavuzarslan, P. 2017. Türk Sözlükçülük Geleneği Açısından Osmanlı Dönemi Sözlükleri ve Şemseddin Sâmî'nin Kâmûs-1 Türkî'si. DTCF Dergisi 44(2): 185-202.

Yıkmış, S. and Ş. Sazak. 2017. Türk sözlükbilimi bibliyografyası üzerine bir deneme (2000-2016). Boz, E. et al. 2017. III. Uluslararası Sözlükbilimi Sempozyumu, Eskişehir, 3-4 November 2016: 780825. Eskişehir: Eskişehir Osmangazi University.

Zgusta, L. 1971. Manual of Lexicography. Janua Linguarum. Series Maior 39. Prague: Academia/The Hague/Paris: Mouton. 